\title{
Serum Leptin Concentration Positively Correlates with Body Weight and Total Fat Mass in Postmenopausal Japanese Women with Osteoarthritis of the Knee
}

\author{
Jun Iwamoto, ${ }^{1}$ Tsuyoshi Takeda, ${ }^{1}$ Yoshihiro Sato, ${ }^{2}$ and Hideo Matsumoto ${ }^{1}$ \\ ${ }^{1}$ Institute for Integrated Sports Medicine, Keio University School of Medicine, 35 Shinanomachi, Shinjuku-ku, Tokyo 160-8582, Japan \\ ${ }^{2}$ Department of Neurology, Mitate Hospital, Tagawa, Fukuoka 826-0041, Japan
}

Correspondence should be addressed to Jun Iwamoto, jiwamoto@sc.itc.keio.ac.jp

Received 11 August 2010; Accepted 5 January 2011

Academic Editor: Marco Amedeo Cimmino

Copyright (C) 2011 Jun Iwamoto et al. This is an open access article distributed under the Creative Commons Attribution License, which permits unrestricted use, distribution, and reproduction in any medium, provided the original work is properly cited.

\begin{abstract}
The objective of the present study was to identify factors correlated with the serum leptin concentration in women with knee OA. Fifty postmenopausal Japanese women with knee OA (age: 50-88 years) were recruited in our outpatient clinic. Plain radiographs of the knee were taken, and urine and blood samples were collected. Dual-energy X-ray absorptiometry (DXA) scanning was performed for the whole body and lumbar spine, and factors correlated with the serum leptin concentration were identified. A simple linear regression analysis showed that body weight, body mass index, whole-body bone mineral density (BMD), total fat mass, and total fat percentage, but not age, height, lumbar spine BMD, lean body mass, serum and urinary bone turnover markers, or the radiographic grade of knee OA, were significantly correlated with the serum leptin concentration. A multiple regression analysis showed that among these factors, only body weight and total fat mass exhibited a significant positive correlation with the serum leptin concentration. These results suggest that the serum leptin concentration might be related to increases in body weight and total fat mass, but not to BMD or bone turnover markers, in postmenopausal women with OA.
\end{abstract}

\section{Introduction}

Leptin, the product of the $o b$ gene, is a peptide hormone secreted primarily by the adipocytes and plays an important role in the regulation of body weight by centrally inhibiting food intake and stimulating energy expenditure [1]. Leptin enters the circulation and crosses the blood-brain barrier to reach its primary target, receptors in the hypothalamus. However, a clinical study has shown that the serum leptin concentration is elevated in obese persons and is correlated with the percentage of body fat [2]. Thus, obesity is more likely to be caused by central mechanisms regulating food intake and energy expenditure than by defective signaling originating in adipocytes and affecting these central mechanisms [2].

Leptin regulates bone metabolism [3]. Leptin decreases bone formation and increases bone resorption via the sympathetic nervous system $[4,5]$. Conversely, circulating leptin also regulates bone metabolism directly by binding to leptin receptors on bone marrow stromal cells, osteoblasts, and osteoclasts, functioning to increase osteoblast activity and decrease osteoclast activity [6]. Clinically, the results of cross-sectional and longitudinal cohort studies examining relationships among the serum leptin concentration, bone mineral density (BMD), and/or bone formation and resorption markers remain contradictory [7-9]. A recent prospective study demonstrated that the initial serum leptin concentration, together with specific-body composition parameters, determined the loss in total and femoral neck BMD values in physically active older women [10].

Osteoarthritis (OA) of the knee is the most common type of arthritis and is the major cause of chronic musculoskeletal pain and mobility disability in elderly populations, representing a significant burden on health care provision. Well-established risk factors for OA include aging, obesity, and female sex [11]. The serum leptin concentration is known to be two to threefold higher in women than in men, independent of adiposity [12]. It has been hypothesized 
that leptin might be a systemic or local factor mediating the metabolic link between obesity and OA and partially accounting for the gender disparity of this disease [13].

Accordingly, leptin was speculated to mediate the metabolic link connecting fat mass, knee OA, and BMD in women. However, very few studies have addressed this issue in women with knee OA. The objective of the present study was to identify possible correlations between the serum leptin concentration and various factors including age, height, body weight, body mass index (BMI), BMD, lean body mass, total fat mass, total fat percentage, bone turnover markers, and the radiographic grade of $\mathrm{OA}$ in women with knee OA.

\section{Subjects and Methods}

2.1. Subjects. Postmenopausal Japanese women with OA of the knee who visited our outpatient clinic (orthopaedics and sports medicine clinic) in 2002 or 2003 were recruited. All the patients had consulted experts in knee OA treatment at our clinic because of knee pain. The diagnosis of OA of the knee was made based on the clinical symptoms, the results of a physical examination, and X-ray findings of the knee. All the patients had mild, moderate, or severe OA of the knee (grades 1-4) according to the Kellgren and Lawrence method of grading (grade 0 , normal; grade 1, possible osteophytes only; grade 2, definite osteophytes and possible joint-space narrowing; grade 3, moderate osteophytes and/or definite joint-space narrowing; and grade 4, large osteophytes, severe joint-space narrowing, and/or bony sclerosis) [14]. Because pharmacological treatments such as oral nonsteroidal antiinflammatory drugs (NSAIDs) and intra-articular injections of hyaluronates are effective for symptom relief $[15,16]$, most of the patients were receiving weekly to monthly intraarticular injections of hyaluronate sodium and/or oral NSAIDs.

After one-month of the cessation of intraarticular injections of hyaluronate sodium, dual-energy X-ray absorptiometry (DXA) scanning was performed on the whole body and the whole lumbar spine. Urine and serum samples were collected from all the patients between 9:00 am and 11:00 am, and the serum leptin and urinary and serum bone turnover markers were measured. Factors correlated with the serum leptin level were then determined. Informed consent was obtained from each patient.

2.2. Measurements of Serum Leptin and Serum and Urinary Bone Turnover Markers. The urinary levels of pyridinoline and deoxypyridinoline were measured using highperformance liquid chromatography (HPLC) (normal range: $17.7-41.9 \mathrm{pmol} / \mu \mathrm{mol} \mathrm{Cr}$ and $2.8-7.6 \mathrm{nmol} / \mathrm{mmol} \mathrm{Cr}$, resp.) [17], and the urinary levels of cross-linked N-terminal telopeptide of type I collagen (NTX) were measured using an enzyme-linked immunosorbent assay (ELISA) (normal range: 9.3-54.3 nM BCE/mM Cr) [17]. The serum levels of bone-specific alkaline phosphatase (BAP) were measured using a chemiluminescent enzyme immunoassay (CLEIA) (normal range: 7.9-20.9 U/L) [17]. The serum levels of osteocalcin (OC) were measured using an immunoradiometric assay (IRMA) (normal range: $3.1-12.7 \mathrm{ng} / \mathrm{mL}$ ).
The serum levels of leptin were measured using a radioimmunoassay (RIA) (normal range: $2.5-21.8 \mathrm{ng} / \mathrm{mL}$ ).

2.3. DXA Scanning. First, DXA scanning was performed on the whole body in the supine position using a Norland XR-36 instrument (Norland, Fort Atkison, WI, USA). The BMD of the whole body, lean body mass, total fat mass, and total fat percentage were measured. Second, DXA scanning was also performed on the lumbar spine in the supine position, and the BMD of the lumbar spine (L2-L4) in the anteroposterior view was measured.

According to the Japanese diagnostic criteria for the diagnosis of osteoporosis $[18,19]$, patients with a lumbar spine or hip BMD $<70 \%$ of the young adult mean (YAM) or of $70-80 \%$ of the YAM and a history of osteoporotic fractures are diagnosed as having "osteoporosis". Patients with a lumbar spine BMD, but not a whole-body BMD, $\geqq 80 \%$ of the YAM and between $70 \%-80 \%$ of the YAM without any history of osteoporotic fractures are diagnosed as being "normal" and having "osteopenia", respectively. Data regarding the YAM for whole-body BMD is not available.

2.4. Statistical Analysis. A simple linear regression analysis was used to examine possible correlations between the serum leptin level and age; body weight; height; BMI; lumbar spine BMD; whole-body BMD; lean body mass; total fat mass; total fat percentage; serum and urinary bone turnover markers including serum BAP and osteocalcin and urinary pyridinoline, deoxypyridinoline, and NTX; and the radiographic grade of knee OA. A multiple regression analysis was used to determine factors correlated with the serum leptin level among the factors that were significantly correlated with the serum leptin level in a simple linear regression analysis. All statistical analyses were performed using the Stat View-J5.0 program on a Windows computer. A significance level of $P<.05$ was used for all the comparisons.

\section{Results}

3.1. Characteristics of Study Subjects. Table 1 shows the characteristics of the study subjects. The mean age was 66.4 years, and the mean BMI was $24.1 \mathrm{~kg} / \mathrm{m}^{2}$ (normal range: $18.5-25.0 \mathrm{~kg} / \mathrm{cm}^{2}$ ), corresponding to a "normal high" level for Japanese populations. The mean lumbar spine BMD was $0.864 \mathrm{~g} / \mathrm{cm}^{2}$, which was $83.1 \%$ of the young adult mean (diagnosed as "normal BMD"). The mean radiographic grade of OA was 2.47. The mean serum leptin level was $9.7 \mathrm{ng} / \mathrm{mL}$ (within normal range). Although the mean urinary pyridinoline and deoxypyridinoline and the serum OC levels were within the normal ranges, the serum BAP and urinary NTX levels were higher than the normal ranges [17].

3.2. Correlations of Serum Leptin Level with Various Factors. A simple linear regression analysis showed that five factors (body weight, BMI, whole-body BMD, total fat mass, and total fat percentage) but not age, height, lumbar spine BMD, 
TABLE 1: Characteristics of study subjects.

\begin{tabular}{|c|c|c|}
\hline & Mean \pm SD & Range \\
\hline Age (years) & $66.4 \pm 8.2$ & $50-88$ \\
\hline Height (m) & $1.56 \pm 0.05$ & $1.47-1.65$ \\
\hline Body weight (kg) & $58.4 \pm 8.2$ & $44-80$ \\
\hline $\begin{array}{l}\text { Body mass index } \\
\left(\mathrm{kg} / \mathrm{m}^{2}\right)\end{array}$ & $24.1 \pm 3.4$ & $16.9-33.3$ \\
\hline $\begin{array}{l}\text { Lumbar spine BMD } \\
\left(\mathrm{g} / \mathrm{cm}^{2}\right)\end{array}$ & $0.864 \pm 0.204$ & $0.524-1.316$ \\
\hline $\begin{array}{l}\text { Whole body BMD } \\
\left(\mathrm{g} / \mathrm{cm}^{2}\right)\end{array}$ & $0.866 \pm 0.108$ & $0.647-1.109$ \\
\hline Lean body mass (g) & $34229 \pm 7548$ & 20720-64203 \\
\hline Total fat mass (g) & $24734 \pm 6135$ & $14302-41201$ \\
\hline Total fat percent $(\%)$ & $40.8 \pm 5.3$ & $29.7-51.5$ \\
\hline Serum BAP (U/L) & $28.1 \pm 9.8$ & $11.7-49.8$ \\
\hline Serum OC $(\mathrm{ng} / \mathrm{mL})$ & $5.7 \pm 2.2$ & $1.7-11.9$ \\
\hline $\begin{array}{l}\text { Urinary } \\
\text { pyridinoline } \\
(\mathrm{pmol} / \mu \mathrm{mol} \mathrm{Cr})\end{array}$ & $32.5 \pm 9.3$ & $19.3-63.6$ \\
\hline $\begin{array}{l}\text { Urinary } \\
\text { deoxypyridinoline } \\
(\mathrm{nmol} / \mathrm{mmol} \mathrm{Cr})\end{array}$ & $6.5 \pm 2.0$ & $2.8-10.1$ \\
\hline $\begin{array}{l}\text { Urinary NTX (nmol } \\
\text { BCE/mmol Cr) }\end{array}$ & $57.9 \pm 21.4$ & $8.2-95.7$ \\
\hline $\begin{array}{l}\text { Serum leptin } \\
(\mathrm{ng} / \mathrm{mL})\end{array}$ & $9.7 \pm 4.7$ & $1.8-21.1$ \\
\hline Radiographic grade & $2.47 \pm 1.00$ & $1-4$ \\
\hline
\end{tabular}

BMD: bone mineral density, BAP: bone-specific alkaline phosphatase, OC: osteocalcin, NTX: cross-linked N-terminal telopeptides of type I collagen, BCE: bone collagen equivalent, $\mathrm{Cr}$ : creatinine.

Normal ranges of urinary pyridinoline, deoxypyridinoline, and NTX were $17.7-41.9 \mathrm{pmol} / \mu \mathrm{mol} \mathrm{Cr}$ and $2.8-7.6 \mathrm{nmol} / \mathrm{mmol} \mathrm{Cr}$, and $9.3-54.3 \mathrm{nM}$ $\mathrm{BCE} / \mathrm{mM} \mathrm{Cr}$, respectively. Normal ranges of serum BAP, OC, and leptin were 7.9-20.9 U/L, 3.1-12.7 ng/mL, and $2.5-21.8 \mathrm{ng} / \mathrm{mL}$, respectively.

lean body mass, serum and urinary bone turnover markers, or the radiographic grade of knee OA were significantly correlated with the serum leptin level (Table 2). A multiple regression analysis showed that among these five factors, body weight and total fat mass were significantly correlated with the serum leptin level $\left(r^{2}=0.859\right.$, Table 3$)$. Figure 1 shows the correlations between the serum leptin level and the body weight and total fat mass according to simple linear regression analyses.

\section{Discussion}

The present study confirmed that the serum leptin concentration was significantly correlated with the body weight and total fat mass in postmenopausal women with knee OA. These positive findings are consistent with the wellknown fact that the serum leptin concentration is closely correlated with fat mass and decreases after weight loss [20]. OA is well known to be strongly correlated with a high BMI [20]. Gonzalez-Gay et al. [21] found a positive correlation between BMI and serum leptin in patients with
TABLE 2: Correlations of serum leptin level with various factors by simple regression analysis.

\begin{tabular}{|c|c|c|}
\hline & Correlation coefficient & $P$ value \\
\hline Age (years) & -0.240 & NS \\
\hline Height (m) & 0.162 & NS \\
\hline Body weight (kg) & 0.792 & $<.0001$ \\
\hline $\begin{array}{l}\text { Body mass index } \\
\left(\mathrm{kg} / \mathrm{m}^{2}\right)\end{array}$ & 0.693 & $<.0001$ \\
\hline $\begin{array}{l}\text { Lumbar spine BMD } \\
\left(\mathrm{g} / \mathrm{cm}^{2}\right)\end{array}$ & 0.255 & NS \\
\hline $\begin{array}{l}\text { Whole body BMD } \\
\left(\mathrm{g} / \mathrm{cm}^{2}\right)\end{array}$ & 0.440 & .0014 \\
\hline Lean body mass (g) & 0.189 & NS \\
\hline Total fat mass (g) & 0.706 & $<.0001$ \\
\hline Total fat percent $(\%)$ & 0.511 & $<.0001$ \\
\hline Serum BAP (U/L) & -0.085 & NS \\
\hline $\begin{array}{l}\text { Serum bone Gla } \\
\text { protein }(\mathrm{ng} / \mathrm{mL})\end{array}$ & -0.267 & NS \\
\hline $\begin{array}{l}\text { Urinary pyridinoline } \\
(\mathrm{pmol} / \mu \mathrm{mol} \mathrm{Cr})\end{array}$ & 0.138 & NS \\
\hline $\begin{array}{l}\text { Urinary } \\
\text { deoxypyridinoline } \\
\text { (nmol/mmol Cr) }\end{array}$ & 0.086 & NS \\
\hline $\begin{array}{l}\text { Urinary NTX (nmol } \\
\mathrm{BCE} / \mathrm{mmol} \mathrm{Cr} \text { ) }\end{array}$ & -0.151 & NS \\
\hline Radiographic grade & -0.110 & NS \\
\hline
\end{tabular}

A simple linear regression analysis was used to examine correlations of serum leptin level with various factors. BMD: bone mineral density, BAP: bone-specific alkaline phosphatase, NTX: cross-linked N-terminal telopeptides of type I collagen, BCE: bone collagen equivalent, Cr: creatinine, NS: not significant.

severe rheumatoid arthritis receiving tumor necrosis factor$\alpha$ (TNF- $\alpha$ ) antagonist therapy. In the present study, a simple linear regression analysis showed a similar correlation in patients with knee OA.

The relationship between obesity and OA is an important public health issue. An experimental study showed that extreme obesity arising from impaired leptin signaling induced alterations in subchondral bone morphology without increasing the incidence of knee OA, suggesting that body fat, in and of itself, might not be a risk factor for joint degeneration [22]. Obesity alone does not cause knee $\mathrm{OA}$, and leptin might be involved in OA because without leptin, obesity itself does not predispose an individual to OA [22]. Leptin receptors have been found in articular cartilage, further implying that leptin synthesis and secretion might play a role in OA [13]. Leptin might play a catabolic role in cartilage metabolism and may be a disadvantage factor involved in the pathological process of OA [23]. Thus, the high concentration of serum leptin in obese individuals might be associated with an increased risk of knee OA. As a result of the effects of sex hormones, the serum leptin concentration is higher in women than in men, even after adjustments for BMI, and this difference might be relevant to the influence of gender on the development and 
TABLE 3: Correlations of serum leptin level with five factors by multiple regression analysis.

\begin{tabular}{lccc}
\hline & Regression coefficient & Standard error & $P$ value \\
\hline Body weight $(\mathrm{kg})$ & 0.331 & 0.123 & .0098 \\
Body mass index $\left(\mathrm{kg} / \mathrm{m}^{2}\right)$ & -0.119 & 0.283 & $\mathrm{NS}$ \\
Whole body BMD $\left(\mathrm{g} / \mathrm{cm}^{2}\right)$ & 1.776 & 4.926 & $\mathrm{NS}$ \\
Total fat mass $(\mathrm{g})$ & $3.145 E-4$ & $1.943 E-4$ & .0275 \\
Total fat percent $(\%)$ & -0.087 & 0.178 & $\mathrm{NS}$ \\
\hline
\end{tabular}

A multiple regression analysis was used to examine correlations of serum leptin level with five factors that had a significant correlation by a simple regression analysis. BMD: bone mineral density, NS: not significant.

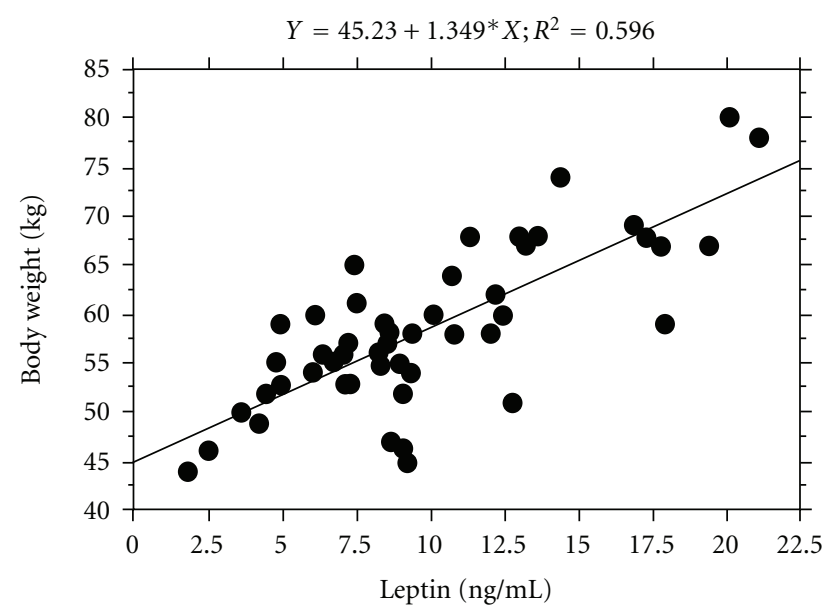

(a)

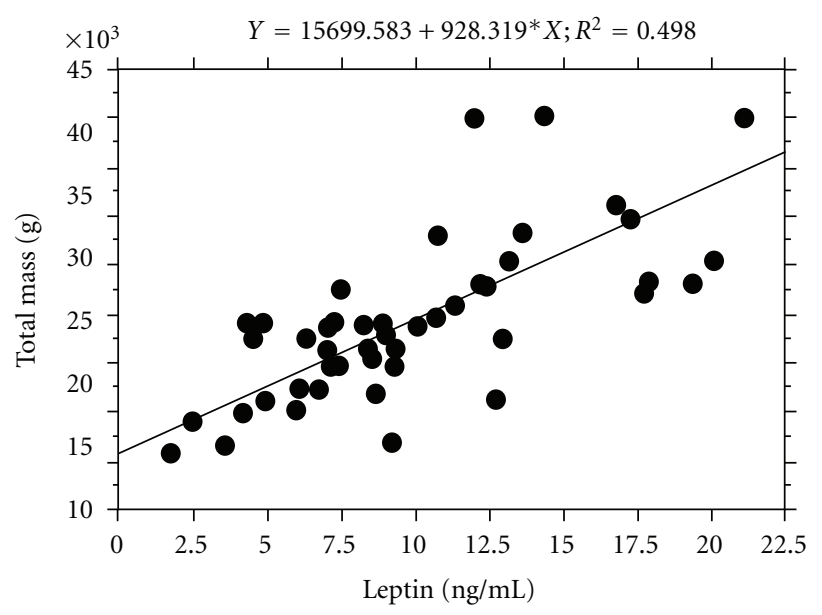

(b)

FIGURE 1: Correlations between the serum leptin level and body weight and total fat mass. A simple linear regression analysis was used to examine correlations of serum leptin level with body weight and total fat mass. Body weight and total fat mass had a significant positive correlation with serum leptin level (both $P<.0001$ ).

frequency of OA [24]. However, the present study did not show any significant correlation between the serum leptin concentration and the radiographic grade of knee OA. Thus, the elevated serum leptin concentrations might not have resulted in an increased risk of knee OA in our subjects.

Studies have shown that patients with knee OA might have a higher bone mineral content (BMC) and bone size, although the relation between knee OA and BMD remains to be established [25-34]. However, Weiss et al. [7] suggest that obese people might have a relatively low level of bone loss and a decreased risk of osteoporosis. The bone-sparing effects of body weight might possibly be caused by increased loading on the skeleton, the increased production of estrogen in adipose tissue, the increased bone formation caused by the anabolic effects of high levels of insulin, and/or high levels of bone-related hormones such as leptin [7]. The present study showed that postmenopausal women with knee OA (mean age: 66.4 years) had a normal lumbar spine BMD and a "normal high" BMI, despite the fact that women older than 65 years have an increased risk of osteoporosis [35]. The normal lumbar spine BMD might partly be attributable to the "normal high" BMI and the subsequent increases in loading to the skeleton. The significant correlation between the serum leptin concentration and whole-body BMD observed in the simple regression analysis disappeared in a multiple regression analysis, suggesting an interaction between body weight or total fat mass and whole-body BMD. The urinary NTX and serum BAP levels in our study subjects suggested that bone turnover was mildly increased, compared with in healthy premenopausal women [17], as a result of menopause, similar to previously reported postmenopausal women with osteoporosis [36]. The serum leptin concentration was not significantly correlated with the $\mathrm{BMD}$ and bone turnover markers, probably because it was not high enough to influence bone formation and resorption and, subsequently, the BMD.

Joint space narrowing, sclerosis of the subchondral bone, and the presence of osteophytes are typical structural features of knee OA. Thus, both articular cartilage and subchondral bone are considered to be involved in the pathogenesis of knee OA. However, recent evidence has shown that increased local bone turnover, decreased BMC and stiffness, and trabecular bone loss have been observed in the subchondral bone structure of knee OA [37-39]; therefore, subchondral bone abnormalities might be a major factor in disease progression. The Framingham Study showed that a high $\mathrm{BMD}$ and $\mathrm{BMD}$ gain decreased the risk of radiographic knee OA progression [40]. Thus, the subchondral bone mass and structure and the whole-body BMD, if it influences the subchondral bone, might be associated with the progression 
of knee OA. In the present study, however, no significant association was found between the radiographic grade of knee OA and the lumbar spine and whole-body BMD (data not shown), probably because of the small sample sizes in the subanalyses.

Weight loss is correlated with a decrease in the progression of OA, and the serum leptin concentration decreases after weight loss [20]. Thus, studying the effect of interventions aimed at weight loss on the progression of knee $\mathrm{OA}$, serum leptin concentration, and BMD in patients with knee OA would be interesting. Adiponectin, an adiposemodulated biochemical signal, might play an important role in the maintenance of the total $\mathrm{BMC}$ and regional $\mathrm{BMD}$ in physically active older women [10]. Thus, examining the correlations among serum adiponectin concentration, the radiographic grade of knee OA, BMD, body size, and fat mass in women would also be interesting. Further research is needed to clarify these issues.

In conclusion, the present study evaluated the serum leptin concentration, the radiographic grade of knee OA, BMD, body size, and fat mass in postmenopausal women with knee OA. The serum leptin concentration and the lumbar spine BMD were normal. However, the BMI was "normal high," probably because of a mild impairment in the central mechanisms of leptin signaling. The present study revealed that body weight and total fat mass, but not the $\mathrm{BMD}$ or the radiographic grade of $\mathrm{OA}$, exhibited a significant positive correlation with the serum leptin concentration in postmenopausal women with knee OA.

\section{References}

[1] Y. Zhang, R. Proenca, M. Maffei, M. Barone, L. Leopold, and J. M. Friedman, "Positional cloning of the mouse obese gene and its human homologue," Nature, vol. 372, no. 6505, pp. 425432, 1994

[2] R. V. Considine, M. K. Sinha, M. L. Heiman et al., "Serum immunoreactive-leptin concentrations in normal-weight and obese humans," The New England Journal of Medicine, vol. 334, no. 5, pp. 292-295, 1996.

[3] V. Cirmanová, M. Bayer, L. Stárka, and K. Zajícková, “The effect of leptin on bone-an evolving concept of action," Physiological Research, vol. 57, no. 1, supplement, pp. S143S151, 2008.

[4] S. Takeda, F. Elefteriou, R. Levasseur et al., "Leptin regulates bone formation via the sympathetic nervous system," Cell, vol. 111, no. 3, pp. 305-317, 2002.

[5] F. Elefteriou, J. D. Ahn, S. Takeda et al., "Leptin regulation of bone resorption by the sympathetic nervous system and CART,” Nature, vol. 434, no. 7032, pp. 514-520, 2005.

[6] F. Elefteriou, S. Takeda, K. Ebihara et al., "Serum leptin level is a regulator of bone mass," Proceedings of the National Academy of Sciences of the United States of America, vol. 101, no. 9, pp. 3258-3263, 2004.

[7] L. A. Weiss, E. Barrett-Connor, D. Von Mühlen, and P. Clark, "Leptin predicts BMD and bone resorption in older women but not older men: the Rancho Bernardo Study," Journal of Bone and Mineral Research, vol. 21, no. 5, pp. 758-764, 2006.

[8] M. Yamauchi, T. Sugimoto, T. Yamaguchi et al., "Plasma leptin concentrations are associated with bone mineral density and the presence of vertebral fractures in postmenopausal women," Clinical Endocrinology, vol. 55, no. 3, pp. 341-347, 2001.

[9] M. Sato, N. Takeda, H. Sarui et al., "Association between serum leptin concentrations and bone mineral density, and biochemical markers of bone turnover in adult men," Journal of Clinical Endocrinology and Metabolism, vol. 86, no. 11, pp. 5273-5276, 2001.

[10] J. Jürimäe, T. Kums, and T. Jürimäe, "Adipocytokine and ghrelin levels in relation to bone mineral density in physically active older women: longitudinal associations," European Journal of Endocrinology, vol. 160, no. 3, pp. 381-385, 2009.

[11] M. Sowers, "Epidemiology of risk factors for osteoarthritis: systemic factors," Current Opinion in Rheumatology, vol. 13, no. 5, pp. 447-451, 2001.

[12] T. Thomas and B. Burguera, "Is leptin the link between fat and bone mass?" Journal of Bone and Mineral Research, vol. 17, no. 9, pp. 1563-1569, 2002.

[13] A. J. Teichtahl, A. E. Wluka, J. Proietto, and F. M. Cicuttini, "Obesity and the female sex, risk factors for knee osteoarthritis that may be attributable to systemic or local leptin biosynthesis and its cellular effects," Medical Hypotheses, vol. 65, no. 2, pp. 312-315, 2005.

[14] J. H. Kellgren and J. S. Lawrence, "Radiological assessment of osteo-arthrosis," Annals of the Rheumatic Diseases, vol. 16, no. 4, pp. 494-502, 1957.

[15] D. T. Felson, "Osteoarthritis of the knee," The New England Journal of Medicine, vol. 354, no. 8, pp. 841-848, 2006.

[16] N. Bellamy, J. Campbell, V. Robinson, T. Gee, R. Bourne, and G. Wells, "Viscosupplementation for the treatment of osteoarthritis of the knee," Cochrane Database of Systematic Reviews, no. 2, Article ID CD005321, 2005.

[17] Y. Nishizawa, T. Nakamura, H. Ohta et al., "Guidelines for the use of biochemical markers of bone turnover in osteoporosis (2004)," Journal of Bone and Mineral Metabolism, vol. 23, no. 2, pp. 97-104, 2005.

[18] H. Orimo, Y. Sugioka, M. Fukunaga et al., "Diagnostic criteria of primary osteoporosis," Journal of Bone and Mineral Metabolism, vol. 16, no. 3, pp. 139-150, 1998.

[19] H. Orimo, Y. Hayashi, M. Fukunaga et al., "Diagnostic criteria for primary osteoporosis: year 2000 revision," Journal of Bone and Mineral Metabolism, vol. 19, no. 6, pp. 331-337, 2001.

[20] L. J. Sandell, "Obesity and osteoarthritis: is leptin the link?" Arthritis and Rheumatism, vol. 60, no. 10, pp. 2858-2860, 2009.

[21] M. A. Gonzalez-Gay, M. T. Garcia-Unzueta, A. Berja et al., "Anti-TNF- $\alpha$ therapy does not modulate leptin in patients with severe rheumatoid arthritis," Clinical and Experimental Rheumatology, vol. 27, no. 2, pp. 222-228, 2009.

[22] T. M. Griffin, J. L. Huebner, V. B. Kraus, and F. Guilak, "Extreme obesity due to impaired leptin signaling in mice does not cause knee osteoarthritis," Arthritis and Rheumatism, vol. 60, no. 10, pp. 2935-2944, 2009.

[23] J. P. Bao, W. P. Chen, J. Feng, P. F. Hu, Z. L. Shi, and L. D. Wu, "Leptin plays a catabolic role on articular cartilage," Molecular Biology Reports, vol. 37, no. 7, pp. 3265-3272, 2009.

[24] O. Gualillo, "Further evidence for leptin involvement in cartilage homeostases," Osteoarthritis and Cartilage, vol. 15, no. 8, pp. 857-860, 2007.

[25] J. Iwamoto, T. Takeda, and S. Ichimura, "Forearm bone mineral density in postmenopausal women with osteoarthritis of the knee," Journal of Orthopaedic Science, vol. 7, no. 1, pp. 19-25, 2002 
[26] K. Naitou, K. Kushida, M. Takahashi, T. Ohishi, and T. Inoue, "Bone mineral density and bone turnover in patients with knee osteoarthritis compared with generalized osteoarthritis," Calcified Tissue International, vol. 66, no. 5, pp. 325-329, 2000.

[27] M. Sowers, L. Lachance, D. Jamadar et al., "The associations of bone mineral density and bone turnover markers with osteoarthritis of the hand and knee in pre- and perimenopausal women," Arthritis and Rheumatism, vol. 42, no. 3, pp. 483-489, 1999.

[28] M. T. Hannan, J. J. Anderson, Y. Zhang, D. Levy, and D. T. Felson, "Bone mineral density and knee osteoarthritis in elderly men and women: the Framingham study," Arthritis and Rheumatism, vol. 36, no. 12, pp. 1671-1680, 1993.

[29] D. J. Hart, C. Cronin, M. Daniels, T. Worthy, D. V. Doyle, and T. D. Spector, "The relationship of bone density and fracture to incident and progressive radiographic osteoarthritis of the knee: the Chingford study," Arthritis and Rheumatism, vol. 46, no. 1, pp. 92-99, 2002.

[30] A. P. Bergink, A. G. Uitterlinden, J. P. T. M. Van Leeuwen, A. Hofman, J. A. N. Verhaar, and H. A. P. Pols, "Bone mineral density and vertebral fracture history are associated with incident and progressive radiographic knee osteoarthritis in elderly men and women: the Rotterdam study," Bone, vol. 37, no. 4, pp. 446-456, 2005.

[31] H. Atalar, B. Yanik, B. Ozcakar, E. Atalar, and A. Koktener, "Bone mineral density is not related to severity of osteoarthritis in the knee in postmenopausal women," Rheumatology International, vol. 28, no. 3, pp. 233-236, 2008.

[32] D. L. Schneider, E. Barrett-Connor, J. Deborah, and M. M. Weisman, "Bone mineral density and clinical hand osteoarthritis in elderly men and women: the e Rancho Bernardo Study," Journal of Rheumatology, vol. 29, no. 7, pp. 1467-1472, 2002.

[33] M. C. Hochberg, M. Lethbridge-Cejku, W. W. Scott, R. Reichle, C. C. Plato, and J. D. Tobin, "Upper extremity bone mass and osteoarthritis of the knees: data from the Baltimore longitudinal study of aging," Journal of Bone and Mineral Research, vol. 10, no. 3, pp. 432-438, 1995.

[34] M. Abdin-Mohamed, K. Jameson, E. M. Dennison, C. Cooper, and N. K. Arden, "Volumetric bone mineral density of the tibia is not increased in subjects with radiographic knee osteoarthritis," Osteoarthritis and Cartilage, vol. 17, no. 2, pp. 174-177, 2009.

[35] S. Fujiwara, "Effectiveness of screening for osteoporosis by bone density measurement for the prevention of fractures: a review of the evidence," Nippon Eiseigaku Zasshi, vol. 58, no. 3, pp. 338-346, 2003 (Japanese).

[36] T. Matsumoto, H. Hagino, M. Shiraki et al., "Effect of daily oral minodronate on vertebral fractures in Japanese postmenopausal women with established osteoporosis: a randomized placebo-controlled double-blind study," Osteoporosis International, vol. 20, no. 8, pp. 1429-1437, 2009.

[37] T. D. Spector, "Bisphosphonates: potential therapeutic agents for disease modification in osteoarthritis," Aging, vol. 15, no. 5, pp. 413-418, 2003.

[38] P. Bettica, G. Cline, D. J. Hart, J. Meyer, and T. D. Spector, "Evidence for increased bone resorption in patients with progressive knee osteoarthritis: longitudinal results from the Chingford study," Arthritis and Rheumatism, vol. 46, no. 12, pp. 3178-3184, 2002.

[39] B. Li and R. M. Aspden, "Mechanical and material properties of the subchondral bone plate from the femoral head of patients with osteoarthritis or osteoporosis," Annals of the Rheumatic Diseases, vol. 56, no. 4, pp. 247-254, 1997.

[40] Y. Zhang, M. T. Hannan, C. E. Chaisson et al., "Bone mineral density and risk of incident and progressive radiographic knee osteoarthritis in women: the Framingham Study," Journal of Rheumatology, vol. 27, no. 4, pp. 1032-1037, 2000. 


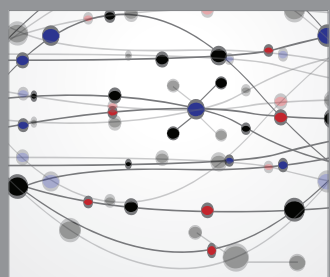

The Scientific World Journal
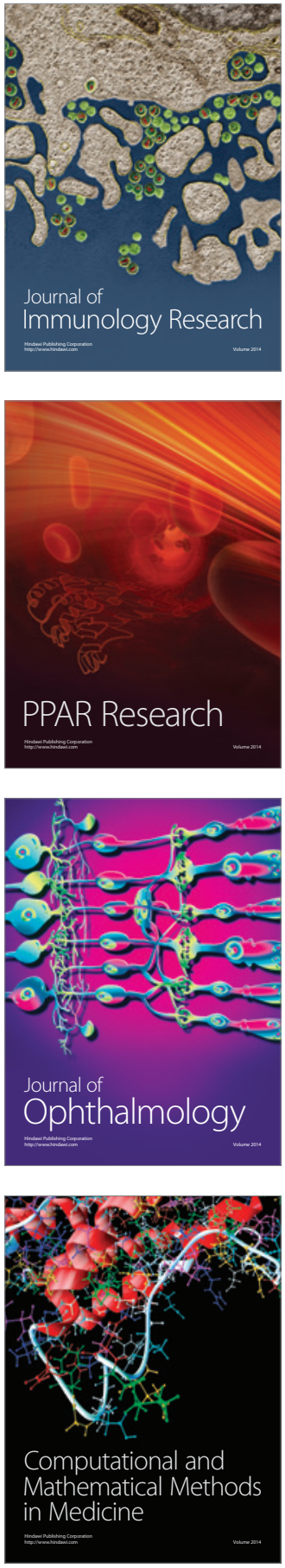

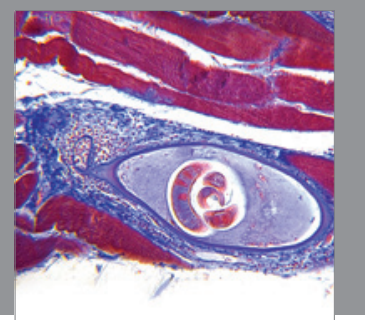

Gastroenterology

Research and Practice
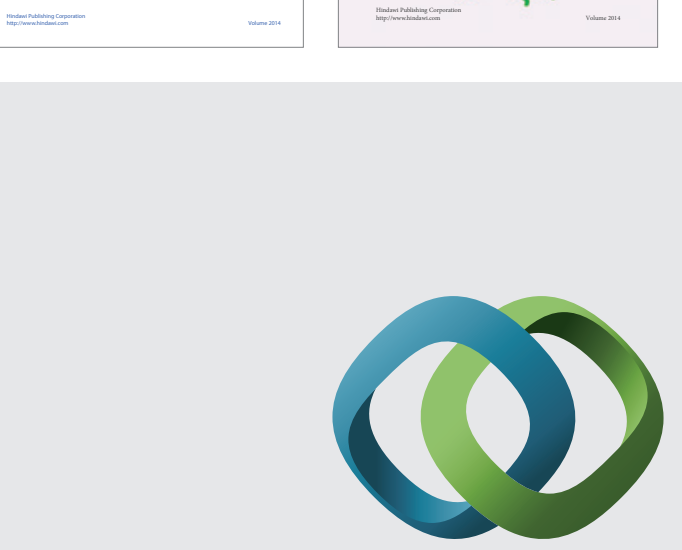

\section{Hindawi}

Submit your manuscripts at

http://www.hindawi.com
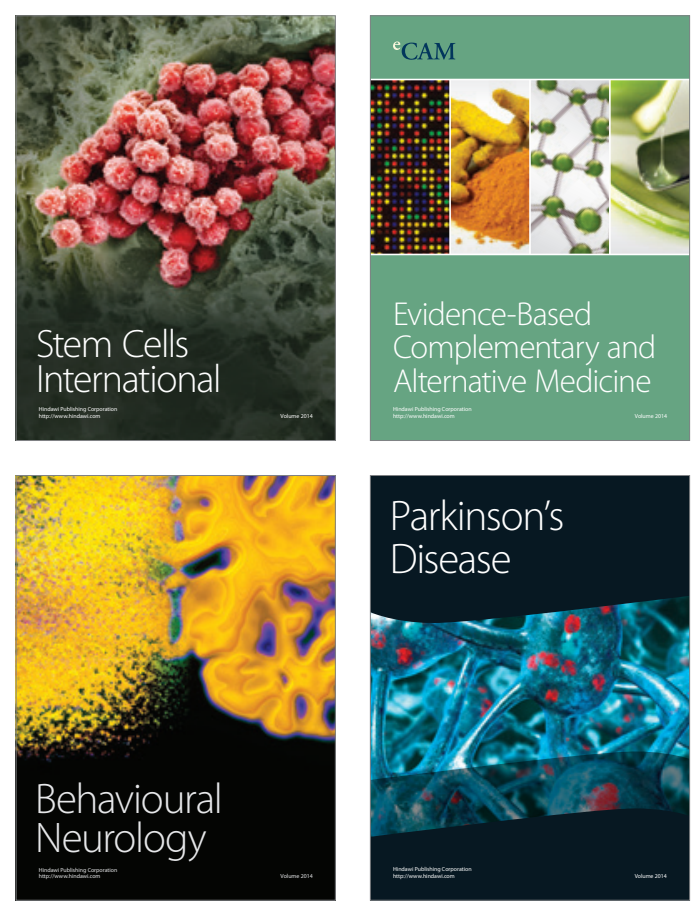

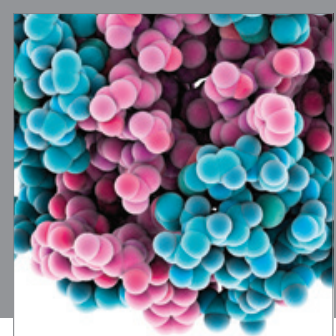

Journal of
Diabetes Research

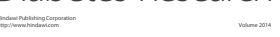

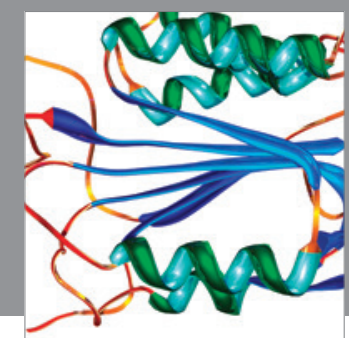

Disease Markers
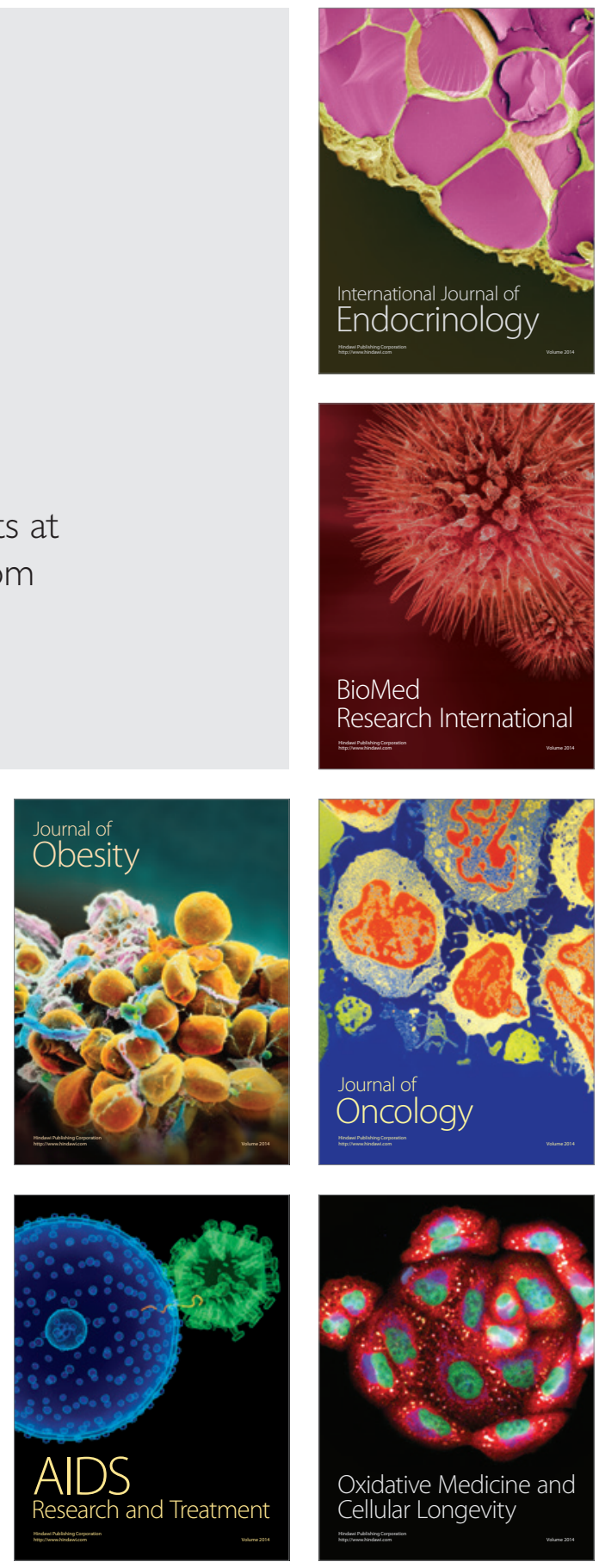